THE UNRULY HORSE

\title{
REFLECTIONS ON THE RULE OF LAW
}

\author{
"The truth is that the rule of \\ law is apt to be an unruly horse \\ ... If analysis is attempted it is \\ found that the idea includes no- \\ tions which are essentially \\ imprecise."
}

(Sir Ivor Jennings: The law and the constitution 60)

\begin{abstract}
Critics often say that certain aspects of South African law or of the South African societal structure constitute infringements of the rule of law. One is left by these critics with a general notion that the rule of law is some sort of Sollensprinzip applying to positive law, i e a criterion for the evaluation of legal rules and systems, and that mainly those measures which are being employed in South Africa to substantiate the policy of separate development in the field of race relations and most of the provisions for safeguarding state security are in conflict with its principles. As such this mystical concept is being used to bring the basic structure of the South African way of living into disrepute; and the urgency of the situation necessitates all who are compelled to plan their future in our sub-continent to take careful note of its exact meaning, function and contents. A philosophical survey of contemporary society within the context of the South African situation will therefore be incomplete if it were to omit an analysis of the rule of law.
\end{abstract}

The mysteries of the rule of law have intrigued lawyers and philosophers for almost a hundred years. Their observations led Sir Ivor Jennings to compare the rule of law with an unruly horse. The truth is, however, that the rule of law resembles a chameleon rather than a horse. For if analysis is attempted it will be found that the idea takes on different shades of meaning to satisfy the subjective prejudices of its interpreters or to cope with a variety of quite irreconcilable situations. Needless to say, such 
fluctuations of meaning are detrimental to the very idea and true relevancy of a basic rule (or basic rules) of law.

In the present context I plan to add my own observations regarding the rule of law to the many other attempts which have been made to bridle the unruly horse. In doing so I will bear in mind the relevancy which such a concept may have in view of the South African societal structure. And in dealing with other expositions of the rule of law, I can understandably only refer to a few of the most important interpretations.

\section{DICEY AND THE RULE OF LAW}

The term "rule of law" was introduced and originally defined by A V Dicey during the second half of the last century to denote the fundamental principles of British constitutional law; and, as pointed out by D C M Yardley, "... any modern discussion of the subject must begin with the theory of Professor A V Dicey ...,"1) because, although the meaning of "rule of law" has undergone many changes since Dicey, “... the influence of Dicey remains a real force." ${ }^{2}$ )

Dicey understood the rule of law to mean the "supremacy of law."3) This idea, which implies basically that both the subordinates and the government of a state are subject to the law, includes three principles: firstly, that transgressions of the law are to be established in accordance with the law in the ordinary legal manner and before the regular courts and that persons in authority are therefore not to be endowed with arbitrary, prerogative or discretionary powers; secondly, that no person is to be above the law and that all persons are therefore entitled to be treated as equals before the law; and thirdly, that constitutional rights of the subjects are to be determined in the ordinary course of justice and that no special significance is to be attached to constitutional law.4)

The whole trend of Dicey's exposition of the rule of law made it quite clear that he was only concerned with basic principles of specifically English law. In its original form the rule of law was never intended to reflect the meaning-kernel or essential characteristics of the law as such; nor was it meant to portray ideal principles of what the law in general ought to be. Although Dicey himself 
obviously preferred the typical British principles of the rule of law to the corresponding constitutional rules of certain other systems, he never professed those principles to be anything but 19th century empirical rules of the English law.

This must be borne in mind when one judges Dicey's critics. The criticism of Hood Phillips, that the rule of law as expounded by Dicey did not coincide with the British concept of parliamentary supremacy, is for that reason unjustifiable. ${ }^{5}$ ) This critique presupposes that the rule of law was meant to operate as a fundamental principle of all law or of all English law, because only in that sense can it be said to contradict the idea that parliament can abolish or amend all laws (including the principles of the rule of law) by reason of its sovereign supremacy. ${ }^{8}$ ) Hood Phillips' description of the rule of law as "a rule of politics"?) was also beside the mark, because, as was pointed out above, Dicey did not intend the rule of law to indicate the legal idea, i e an aggregate of principles of what the law ought to be. The same applies to Verloren van Themaat's supposition that the rule of law comprises "state morality, or rules of decency in politics", and that, as such, it must not be seen as a juristic concept. ${ }^{8}$ ) In passing it should also be noted that Verloren van Themaat operates with a narrow positivism which supposes that the legal idea, not being positive law, falls outside the realm of the juristic sphere of reality.

Immanent critique of Dicey's doctrine of the rule of law ought to be based on Dicey's own concept of the rule of law. The inquiry should therefore simply be whether the principles of the rule of law, as stated by Dicey, were in fact reflected in the English constitutional law of his time. Adhering to this basic rule of immanent critique, Wade and Phillips pointed out convincingly that this was not the case..$^{9}$ ) To mention only a few examples: Dicey's first principle, i e the one contra arbitrary powers, did not allow for the delegated law-making competencies and discretionary powers of members of the executive; the second principle, which in general affirmed the subjection of state officials to the "ordinary" laws and the jurisdiction of regular courts, lost sight of the privileges and immunities of certain public officials, diplomats and other persons in authority and was not borne out by the system of administrative judicature; and the third prin- 
ciple, according to which the rights of the subjects were supposed not to be derived from constitutional law, was contradicted by the statutory granting of certain rights and freedoms.

\section{RESTATEMENT OF THE RULE OF LAW BY WADE AND PHILLIPS}

Wade and Phillips therefore found it necessary to restate the rule of law. They reduced the principle contra arbitrary powers to the rule "that, so far as punishment for offences is concerned, the citizen can foresee the consequences of his conduct and will not be punished save for a breach of the ordinary law. He will, moreover, be tried in the ordinary courts." ${ }^{10}$ ) The principle which portrayed Dicey's distrust of delegated legislative powers was reformulated by Wade and Phillips to read "that powers should be defined by law and that any abuse of power or other wrongful act by public officers should be subject to control by the courts in the same way as any wrongful act committed by a private citizen." "11) Finally, Wade and Phillips rephrased Dicey's third principle as follows: "The citizen whose fundamental rights are infringed may seek his remedy in the courts and will rely, not upon a constitutional guarantee, but on the ordinary law of the land." ${ }^{12}$ )

Wade and Phillips' restatement of the rule of law also implies a significant change regarding the very nature of that concept. Whereas Dicey professed that the rule of law simply reflected the basic principles of English law as an empirical system, Wade and Phillips transformed the rule of law into a Sollensprinzip of what the law ought to be. The rule of law was no longer to be "a fixed principle of law," but became "a guide to conduct by any political party which is in a position to influence the course of legislation." ${ }^{13}$ )

As such the rule of law was interpreted by Wade and Phillips to mean "that the exercise of powers of government shall be conditioned by law and that the subject shall bot be exposed to the arbitrary will of his ruler." ${ }^{14}$ ) That implies "the absence of arbitrary power; effective control of and proper publicity for delegated legislation, particularly when it imposes penalties; that when discretionary power is granted the manner in which it is to be exercised should as far as is practicable be defined; that every man should be responsible to the ordinary law 
whether he be private citizen or public officer; that private rights should be determined by impartial and independent tribunals; and that fundamental private rights are safeguarded by the ordinary law of the land." ${ }^{15}$ )

By transferring the rule of law to the sphere of legal ideas Wade and Phillips obviated the critique founded on Dicey's premise that the rule of law reflected basic principles of empirical English law. But, then, it is equally true that Wade and Phillips have abandoned the original meaning of the rule of law.

\section{OTHER STANDARD INTERPRETATIONS OF THE RULE OF LAW}

Almost every text-book dealing with British constitutional law contains an attempt to improve on Dicey's concept of the rule of law. Suffice it for present purposes to refer to only a few of these attempts.

Sir Ivor Jennings shared the view with Wade and Phillips that the principles which Dicey found to be inherent in the concept of the rule of law did not, in fact, reflect the positive law of England as an empirical system. He championed the idea that the rule of law should be rephrased to designate a democratic form of government as against a dictatorship. In that sense it would come to mean "that political power rests in the last analysis on free elections, carried out in a State where criticism of the Government is not only permissible but a positive merit, and where parties based on competing policies or interests are not only allowed but encouraged."16) In such a system, he said, the principles which are usually associated with the rule of law will follow automatically; i e separation of powers, equality of all before the law "irrespective of race, religion, colour, social importance, or wealth" and the impartial application of the law to all "citizens," and a freedom which, according to Jennings, can be felt rather than analysed and which excludes, amongst others, the use of "unconscionable means" for acquiring evidence, espionage, unnecessary restrictions of freedom of movement and of speech and especially of thought. ${ }^{17}$ ) The status of the opposition, said Jennings, indicates whether a country is really free. ${ }^{18}$ ) 
According to Hood Phillips the rule of law is significant in three respects: firstly, it influences the legislator (as Sollensprinzip for legislation); secondly, it provides a rule of interpretation in the sense that all statutory law must be interpreted in such a way that freedom of the subject (especially freedom of the person) is left intact as far as possible; thirdly, it contains a rule of evidence in that all are to be regarded as equals before the law and that any person who professes a special right, power, privilege or immunity must prove his claim. ${ }^{19}$ )

Then there are also those writers who kept to the original meaning of the rule of law in the sense of "supremacy of law." ${ }^{20}$ ) That meaning of the term was said ${ }^{21}$ ) to have originated in Bracton's dictum: "Ipse autem rex, non debet esse sub homine, sed sub deo et sub lege, quia lex facit regem." ${ }^{22}$ ) Some writers even trace the history of the concept of supremacy of the law back to Aristotle, who remarked: "The rule of law then ... is preferable to the rule of an individual citizen." ${ }^{23}$ ) Ridges ${ }^{24}$ ) discovered a close relationship between "rule of law" in that sense and the very famous section 29 of the Magna Charta:25) and in view of this original meaning of "rule of law" he remarked: "The idea that all governmental powers rest on law lies at the basis of the Constitution." ${ }^{26}$ )

A variation on the same theme is to be found in the very interesting exposition of the concept of rule of law by an American author, A L Goodhart. ${ }^{27}$ ) He first rejects the identification of the rule of law with a democratic form of government and with "the idea of basic rights." "... the rule of law," he says, "is the machinery by which effect can be given to such basic rights as are recognized in any particular legal system." ${ }^{28}$ ) The rule of law in that sense is constituted by means of "the con trol which is exercised over the public officers of the State by means of law." ${ }^{29}$ ) Briefly the rule of law is "a rule which controls the public officers of the State" ${ }^{0}$ ) and as such the rule of law does not mean "rule by law" but "rule under the law."31) For that reason Goodhart prefers to use the expression "government under law" rather than "rule of law."32)

This clever play upon words has more to it than first meets the eye. Goodhart's formula, like that of Aristotle quoted above from The Politics, accentuates the meaning of "rule" in the sense of "govern." Goodhart rightly pointed out that if "rule of law" were to be identified with "rule 
by law", then totalitarian states, which restrict freedom in a radical sense with the aid of far-reaching laws, can also claim that they uphold the rule of law. "Rule under the law," however, implies that the state authority, including the executive, legislative and judicial branches of government, is to govern subject to the law. For the effective functioning of the rule of law in that sense Goodhart formulated three essentials: provision must be made for sufficient processes for enforcing the rule; state officials must admit that they are subject to the law; and the society as a whole must realise that the implementation of the rule of law depends upon the will of every individual.

The same idea finds expression in the German term for "rule of law", i e Rechtsstaatsprinzip. Theodor Maunz described a law-state as "ein Staat... der die Forderung nach formeller Gesetzlichkeit in möglichster Vollendung (Perfektionierung) verwirklicht;" and he attributed the following characteristics to such a state: "das Prinzip der Gesetzmässigkeit der Exekutive, die richterliche Kontrolle der Gesetzmässigkeit in Verbindung mit richterlicher Unabhängigkeit und weitestgehender Rechtsweggarantie, der Vorrang und der Vorbehalt des förmlichen Gesetzes, die Voraussehbarkeit und Berechenbarkeit der staatlichen Massnamen und die aus alledem hervorgehende Rechtssicherheit."33) Rechtsstaatsprinzip therefore gives expression to the idea that state authority is subordinate to the law and that government is to be performed subject to legal rules.

\section{THE RULE OF LAW AND HUMAN RIGHTS}

Since the Second World War (1939-1945) the concept of rule of law has undergone changes which affect both its significance and meaning. Firstly, the idea of a rule of law has been internationalised to become "a matter of universal discussion and endeavour to formulate the basic elements of the rule". ${ }^{34}$ ) Secondly, the rule of law came to be identified with the doctrine of human rights.

Both of these changes were stimulated by the Universal Declaration of Human Rights which was formulated under the auspices of the United Nations Organisation in 1948. Mention of "the rule of law" in the preamble of the Declaration ensured the world-wide prominence of that 
concept. At the same time the Declaration constructed a link between the rule of law and the doctrine of human rights by asserting "that human rights should be protected by the rule of law." The concept of "rule of law" was soon adopted by the International Commission of Jurists to serve as a collective term for all those legal principles which the Commission regards as essentials for the implementation of the doctrine of human rights. In my opinion the I $\mathrm{C} \mathrm{J}$ is largely responsible for the fairly general acceptance of the interpolated meaning of "rule of law" as a prerequisite for the protection of human rights.

In view of this interpolated meaning of the rule of law Wade and Phillips stated: "The rule of law has come to be regarded as the mark of a free society ... everywhere it is identified with the liberty of the individual." ${ }^{35}$ ) Yardley put it as follows: "Providing the aim is the preservation of the liberty and rights of all members of the community, and that only such exceptions from this aim as are essential to the administration of the nation in an orderly fashion .... the purpose of the rule of law will have been fulfilled." ${ }^{36}$ )

The particular human rights which have come to be associated with the rule of law are, according to Yardley, "freedom of the person to behave as he pleases, equality before the law, freedom of property, the right to free election, freedom of speech and to write, freedom of public worship, freedom of assembly and association, and family rights. ${ }^{37}$ ) Wade and Phillips in turn gave particular prominence in the second part of their work on British constitutional law to "freedom of person and property" and "liberty of discussion." ${ }^{38}$ )

\section{SOUTH AFRICAN INTERPRETATIONS OF THE RULE OF LAW}

In dealing with South African interpretations of the rule of law I will restrict myself to generalities. For a more elaborate and critical survey of some of the most important expositions of the rule of law by South African authors, the reader can be referred to the commendable analysis by F Venter, entitled: The Withering of the "Rule of Law." ${ }^{39}$ ) 
At the outset I would like to stress that South African interpreters and critics of the rule of law find themselves in a societal situation which is excellently suited for exposing the true meaning, relevancy, merits and demerits of that concept. Opponents of the South African racial policy and critics of its security legislation, who at the same time profess to be disciples of the rule of law, have chosen to focus the debate regarding the pros and cons of that policy and legislation on the rule of law; and the attributes of a concept such as "rule of law" can in any case best be demonstrated with reference to situations in which it operates under strain. Officials and supporters of the South African government have often in the past reacted by denying the meaningful existence or by exposing supposed deficiencies of a rule of law. In South Africa exponents and opponents of the doctrine of the rule of law, therefore, find themselves confronted face to face with one another in a lively debate focussed on concrete empirical problems of vital importance. One would at least expect that this debate will disclose every angle of the unruly horse.

A cross-section of the South African interpreters of the rule of law are of the old school, reverting to the Dicinian paraphrase. But understandably, they too were compelled to interpolate, because in its original form the "rule of law" indicated a set of empirical rules of specifically English constitutional law; and as such the rule of law could hardly have any meaningful relevancy for purposes of the South African law. South African writers therefore invariably regard the rule of law as a universal principle which operates in the realm of the legal idea, i e as a principle founded on ethics and applying to all legal systems with reference to what (the basic function of) the law ought to be. But, although the transformation of the rule of law from an English legal concept into a universal legal idea is radical in its nature. South African interpreters, generally speaking, endeavour to keep to the Dicinian contents of the term.

In this sense Beinart"v) distinguishes between the "central meaning" and a "secondary sense" of the rule of law, the central meaning being "that the law rules or is supreme in every society - lex suprema est - that is, that all rules or powers must derive from duly enacted or established law," $" 1$ ) and the secondary sense being "that 
the legal system should be organised on a basis of detailed predetermined rules." ${ }^{42}$ ) In the latter sense, which Beinart describes as the "true sense," 43 ) the rule of law amounts to the principle of legality as against "the rule of discretion in which the rights of persons are determined by others exercising a lawful discretion but without reference to detailed legal rules ..."44)

Similarly Donald Molteno ${ }^{45}$ ) postulates, with regard to the rule of law, "that it involves general rules, as opposed to arbitrary discretion; that such rules avail against the State itself;" and adds "that their administration is entrusted to an independent and impartial judiciary."46)

Schreiner equally adheres to a "formal" meaning of the rule of law. In countries where public order exists, he says, the rule of law relates to "the control by the law, i e, the rules or precepts recognised by the courts, over the actions of the executive and the legislature in their dealings with the individual." ${ }^{47}$ ) Elsewhere he quotes an earlier statement made by himself in which he defined the rule of law in the following terms: "The Rule of Law means the law should rule; in other words, that the life, liberty, property, freedom of speech and movement of the individual should not be endangered or restricted by state action save in accordance with a general precept applicable to all persons in circumstances set out in the law, the applicability of the general precept to a praticular person being decided by a court of law." ${ }^{4}$ )

Finally, A S Mathews also commits himself to the principle of legality as "an essential element in all definitions of the Rule of Law except the formalistic one ..."48) The principle of legality, which Mathews finds to be "implicit rather than explicit in Dicey's doctrine of the Rule of Law," ${ }^{\circ 0}$ ) expresses the idea of "government according to law"s1) and presupposes the law to be a régime of known and certain rules." ${ }^{52}$ ) In an earlier publication Mathews described this "great principle... fundamental to Dicey"s doctrine" as one which postulates "that ruler and subject alike shall be under law." ${ }^{\text {"53) }}$

The common feature of all the definitions so far is that they reduce the rule of law to its most literal and fundamental meaning of legality, which implies, briefly, that both ruler and subject of a state are governed by the law. In this formal sense the rule of law relates, as Beinart 
puts it, to "the mechanics or structure of the legal system and not to the substance or content of its various laws." ${ }^{54}$ ) As such it poses a serious problem to those exponents of the concept who champion the rule of law as the bulwark of liberal ideals. The problem is that the most despotic and absolutist states can be constituted in such a way that the law can be said to govern the ruler and the subject, and the rule of law in the formal sense of legality can prevail by actually authorising radical inroads into the rights and freedoms of the subjects. In a word, the rule of law in the formal sense of legality does not guarantee justice or the protection of human rights and civil liberties.

For this reason South African authors invariably endeavour to read substance into the rule of law - often contrary to their own initial premises in this regard. For instance, Beinart regards attempts to construct the rule of law "itself to cover also the substantive content of the legal system" as "neither justifiable nor necessary," but then immediately proceeds "to give body to the Rule of Law;" ${ }^{55}$ ) and in so doing he formulates "minimum standards of justice" 56 ) which I find difficult to distinguish from "the substantive content of the legal system" and which he himself eventually describes as "a number of principles ... which can and have been given expression and formulation in legal terms in the common law, in statutes or in constitutions." ${ }^{57}$ ) It is on the whole quite obvious that Beinart regards, amongst others, the protection of human rights to be the concern of the rule of law, or, as he himself put it, that "the principles of the Rule of Law lean in favour of the individual, and serve individual rights;" ${ }^{58}$ ) that "the Rule of Law can be said to function best in a free society, and to be closely associated with the rights of the individual;"59) or that "the Rule of Law is an indispensable requirement for the preservation of civil liberty."60)

In giving substance to the rule of law Molteno similarly concludes that "the rule of law is concerned with the protection of individual legal rights and liberties" and that "the rights and liberties in question are enforceable against, and protected by, the State." ${ }^{1}$ ) Molteno derives this substantive meaning of the rule of law which concerns human rights from Dicey's third proposition, ${ }^{62}$ ) thereby obviously reading more into it than Dicey him- 
self intended. Dicey's concern was simply for the common law protection of rights as against constitutional entrenchments and he certainly did not mean to convey his sympathy for the doctrine of human rights when he formulated any of the principles inherent in the rule of law. Molteno's suggestion, that "Dicey's conception of the Rule of Law still holds the field as the essential safeguard of personal liberty, including the classic liberties and rights associated therewith, such as those of expression, religion, association, peaceful assembly, and so forth," therefore, in my opinion, rests on a misconception of Dicey's clear intention.

Mathews also poses the question whether "the rule of law be the rule of any law or only law which conforms to certain standards derived from disciplines outside the law?"63) In answer to his question he assumes a "clear belief" on the part of Dicey "that the law governing the relation of the subject to the State should reflect certain liberal values to which he (Dicey) subscribed;" ${ }^{64}$ ) and in giving substance to this assumption in his thesis on $L a w$, Order and Liberty in South Africa he, amongst others, "boldly identifies the Rule of Law with the protection of certain basic freedoms" ${ }^{65}$ ) - surprisingly so, since he at the same time emphatically rejects as unscientific "the identification of human rights or of a particular philosophy (as in natural law) with the Rule of Law." ${ }^{6}$ )

Let me also refer to an Afrikaans exponent of the rule of law, A J G M Sanders, ${ }^{67}$ ) who steered clear of the principle of legality by taking a short cut to the doctrine of human rights, thereby avoiding the fundamental meaning of "rule of law" in order to oblige the I C J's conception of the rule of law. Sanders defines the rule of law as follows:

"The rule of law is that legal-political code of conduct applying to state authority which in a given time is best suited to secure to the individual the maximum pleasure and to guarantee those rights of a citizen which, in view of the existing circumstances of the political society concerned, are regarded as fundamental, taking the equal rights of other members of the society and the justified claims of state authority into consideration." 68 ) According to Sanders' vision the main function of the rule of law is supposed to be to support the implementation of human rights.6.$^{69}$ His positivistic point of departure, ${ }^{70}$ ) together with his supposition that the rule of law is to be regarded as "a legal-political code of conduct," ${ }^{71}$ ) places 
the juridical nature of the rule of law in issue, because positivism presupposes that positive law is the only juridical reality.

This problem regarding the juridical nature of the rule of law is also among Mathews' preoccupations. In providing the rule of law with material substance he advocates "the subjection of that part of the law which governs the relationship of the citizen to the State to moral scrutiny." $\left.{ }^{\prime 2}\right)$ The rule of law, he says, "is the application of certain moral judgments to a defined branch of the law and a study of the techniques and devices whereby the values inherent in these judgements may be achieved through law."73) This is, to say the least, careless phrasing which suggests that the rule of law is a sort of scientific technique. But be that as it may, Mathews postulates that the rule of law "is, or ought to be, juridical in its character," 74 ) but it is not at all clear how he intends to maintain the juridical character of the rule of law while its function is to subject a division of the law to moral scrutiny.

The truth is that the legal idea, which may be found to include the rule of law. is necessarily juridical in its nature even though it anticipates ethical principles. To put it in another way: ethical norms can only serve as legal ideas after they have been rephrased in the form of juridical principles, that is principles capable of being transformed into juridical rules. As long as the rule of law remains oriented to the juridical meaning-kernel it will necessarily be juridical in character.

In my view the rule of law in its historical and literal sense simply means legality, which means, as Marinus Wiechers puts it, "that an act, or in a broader sense, an action, must be performed in accordance with the law." "ד) In connection with the rule of law legality refers to the acts and actions of both the rulers and the subjects of a state. But it means nothing more. Wiechers pointed out that attempts to identify the rule of law with democratic or liberal political theories do not take the requirements of the modern welfare states into account ${ }^{78}$ ) and that such attempts make it even more difficult to determine the juridical meaning of that concept. ${ }^{77}$ ) But there is more to it than just that. Attempts to condense all liberal political ideals in to a single concept indicated by the term "rule of law" have only led to confusion and diversities of opinion 
and have clothed the rule of law with such vagueness of meaning that one may very well doubt the meaningful relevancy of such a term. Schreiner rightly remarked: "If that concept (i e 'rule of law') is not sufficient to achieve the good life, by all means put forward new proposals, but do not, I suggest, use the old name as if it has imperceptibly acquired a wholly new meaning." ${ }^{78}$ )

The need felt by some writers to clothe the rule of law with a liberal substance was in all probability based on a false (non-existent) problem. It was, I imagine, the belief of those interpreters that if the rule of law were to mean simply legality, legislators would be at large to ordain despotism and injustice within the framework of the rule of law. In a sense that is true, but it must also be borne in mind that legislative sovereignty does not amount to an omnipotent law-making competency. The lawgiver derives legal rules from juridical principles. Some of those principles have a constitutive and others have a regulative function with regard to positive law; that is, positive law is based on constitutive juridical principles as a matter of necessity, while regulative juridical principles merely serve as a Sollenprinzip of what the law ought to be.

It is sufficient, for present purposes, to quote a single example to illustrate the point. Section 2 of the Republic of South Africa Constitution Act, $1961,{ }^{79}$ ) which reads: "The people of the Republic of South Africa acknowledge the sovereignty and guidance of Almighty God," is obviously not a legal norm, the reason being that this formula lacks an essential constitutive juridical principle, $i$ e the juridical meaning-kernel of retribution. In form and character section 2 of the Constitution contains a confession of faith and the mere fact that it was enacted in a parliamentary statute cannot transfigure it into a legal norm.

Juridical principles which anticipate ethical norms apply as regulative ideas of what the law ought to be. There is no need to incorpora te those principles into one's concept of the rule of law; and in not doing so one does not distract one inch from their validity as normative regulative principles. Those regulative principles with an ethical foundation, and not the principle of legality, serve as an ideal which lawgivers should endeavour to incor- 
porate into positive law and as a criterion for the evaluation of the merits and demerits of a legal system. But of course, if one regards the principle of legality as a juridical principle with an ethical foundation, then the rule of law must be seen as one of the regulative juridical principles with which the law ouht to comply.

\section{CALVINISM AND THE RULE OF LAW}

In his article on The Withering of the "Rule of Law" $F$ Venter points out that those interpreters of the rule of law who identify that concept with the doctrine of human rights base their arguments on a humanistic point of departure which is directly opposed to the theocentrical approach to our problem present in Calvinism. ${ }^{80}$ ) It must, however, be stressed that Calvinism does not deny the existence or relevancy of a rule of law in the sense of legality, or of particularly precious human rights but rebels against humanistic endeavours to make man or human reason the measure and sole consideration of such a rule or such rights.

The anthropocentric approach of humanism introduces, in the present context, a highly subjective element into the concept of rule of law, causing the content of the rule of law to vary and sway according to the whims and fancies of its interpreters. This, according to Mathews, is no crime and is, on the contrary, a sine qua non for ", any useful conception of the rule of law."81) It is, of course, true that every interpretation carries with it a subjective element, but Mathews was here concerned with more than the merely personal prejudices which influence one's vision of reality. The "subjective notions" of which he speaks in the present regard concern his subjectivistic conviction that moral judgments have no fixed and certain basis but rest wholly on one's personal and subjective predilections.

Calvinism, on the other hand, with historic Christianity, maintains that ethical norms, like all other kinds of norms as well as all natural laws which regulate the cosmic order, do have a fixed foundation. Although one's view of those norms and laws will always portray one's individual subjectivity, their essential structures are rooted in creation itself as revealed in the Holy Scripture and will always remain constant. This applies both to the constitutive juridical principles, which find expression 
in positive law, and the regulative juridical principles, which are destined to direct the way to ideal laws. In so far as those principles are founded on the normative side of reality, their contents can and should vary according to the varying demands of the relevant time, place and circumstances, but the invariability of their characteristic structures sets definite limits to fluctuations of their meaning and contents. Calvinism can therefore never subscribe to the view that a sovereign lawgiver who does not uphold the rule of law is free to legislate as and whatever he pleases. To be valid laws, the expressions of a despot's will must bear evidence of the structure of the law as such and of the constitutive juridical principles which underlie every juridical norm, and the regulative principles with their ethical foundation will always remain operative as the lawgiver's conscience.

Looked at from another angle, it amounts to the following: Calvinism does not rely on the rule of law to safeguard the realisation of principles with an ethical foundation in positive law. Those principles apply as regulative juridical principles of what the law ought to be, irrespective of whether the lawgiver and government regard themselves as above the law or, on the other hand, as subordinates of the law. And, whereas humanism bases its preferences for what the law ought to be on the relatively arbitrary notions of its exponents regarding the flexible needs of man, Calvinism derives the legal idea from regulative principles fixed upon the structure of creation and to be discovered in the invariable Word of God.

\section{CONCLUDING REMARKS}

The rule of law simply means legality, that is that both the government and the subordinates of a slitle are subject to the law. The principle of legality as such does not necessarily preclude unjust laws, and a lawgiver with relatively arbitrary powers will not necessarily always proclaim unjust laws. The rule of law, therefore, does not serve as a guarantee for libertarian laws. Nor need one interpolate the rule of law to cope with injustice, because other juridical figures, namely regulative juridical principles, serve the purpose. Attempts to increase the ambit of the rule of law, so as to proclaim it to be the cornerstone of individual rights and civil liberties, have only ler to confusion and should be abandoned. 
The subjection of subordinates of state authority to the law poses no problem in the present context. The main concern of the rule of law has always been for the subjection of state authority to the law. In conclusion I wish to indicate a few of the more important implications of the rule of law in this regard.

State authority which ought to operate subject to the law includes all the branches of government, i e the legislative, executive and judicial power.

Subjection of the legislative department of government to the law implies that legislation ought to be performed in accordance with legal rules, that attempted legislation which does not comply with the procedure for legislation as prescribed by law ought to be regarded as pro non scripto, and that the law ought to provide for a judicial body with competency to enquire into the procedures followed by the legislative organ and to declare such acts of the legislature which do not comply with the prescribed formalities to be void.

Subjection of the executive department of government to the law in its strict sense excludes discretionary powers of the executive. It can, however, be taken for granted that it would not be expedient in modern states to eliminate the discretions of executive officials, and there is much to be said for the view that the rule of law should be moderated in this regard so as not to exclude discretionary powers altogether but only to require such powers to be executed within definite and certain bounds.

Subjection of the judicial department of government to the law implies that courts of law ought to apply the law as they find it within the limits set by the law for their operation. On the other hand they ought not to be subjected to any other limitations than those prescribed by law and ought to be placed in a position in which they can function without bias and without fear of intimidation.

Finally I think it is implicit in the rule of law that the law which governs both the ruler and the subjects ought to be clearly understandable, ought to apply generally to all subjects or to all subjects of a given class, and ought never to operate retroactively. 
In this sense of legality the rule of law can provide the framework for the realisation of egalitarian and libertarian principles but does not operate as a sine qua non for the implementation of such principles. It serves justice but does not guarantee it. It nevertheless remains a very relevant and useful concept, namely one which stresses the need to define the limits of all branches of governmental authority in clear and unequivocal terms and which is destined to restrict arbitrary powers.

\section{J.D. VAN DER VYVER}

JOHAN DAVID VAN DER VYVER was born in Pietermaritzburg on 21 February 1934. In 1974 he received the LL D degree from the University of Pretoria on a thesis on Human Rights. In 1970 he was appointed as professor in Legal Philosophy at the $\mathrm{P} U$ for $\mathrm{CHE}$ and in 1972 through 1974 he was Dean of the Faculty of Law. He is the author of four text-books and he has published a number of articles in various scientific journals.

PRESENT ADDRESS: 13 Postma Street, Potchefstroom, Rep of South Africa. 


\section{NOTES}

1. Introduction to British constitutional law, London 1964, 59.

2. E C S Wade \& G Phillips: Constitutional law: An outline of the law and practice of the constitution including central and local government, the citizen and the state and administrative law, 8th ed by E C S Wade \& A W Bradley, London 1970, 63.

3. Introduction to the study of the law of the constitution (1885) 10th ed, London 1959, 184.

4. Idem, 188-203.

5. Cf O Hood Phillips: The principles of English law and the constitution, London 1939, 62; Constitutional and administ rative law, 4th ed London 1967, 38.

6. In fairness towards Hood Phillips it should be pointed out that he did qualify his critique in this sense. In English law and the constitution loc cit he remarked: "In so far as Dicey's general statement of the Rule of Law has been held to involve the existence in the English Constitution of certain principles almost amounting to fundamental laws, ..." Cf also Constitutional and administrative law loc cit.

7. English law and the constitution 62-3: "It is a political theory in some of its aspects connected with the doctrine of the separation of powers." Cf also Constitutional and administrative law 38.

8. J P Verloren van Themaat: Staatsreg, 2e uitgawe deur M Wiechers, Durban 1967, 123-4.

9. Op cit, 65-74.

10. Op cit, 66

11. Op cit, 70

12. Op cit, 74

13. Op cit 77 .

14. Op cit, 62.

15. Op cit, 76-7.

16. The law and the constitution, 5 th ed London 1959, 60.

17. Op cit, 61.

18. Op cit, 62

19. English law and the constitution 63; Constitutional and administrative law 39.

20. Cf Dicey op cit, 184

21. Cf Hood Phillips: Constitutional and administrative law 33

22. De legibus et consuetudinibus angliae, libri quinque, Londini $1640,1.8 .5$

23. The politics (translated with an analysis and critical notes by J E C Welldon) London 1901, 3.16.

24. Constitutional law (8th ed by G A Forrest), London 1950, 8-8 note7, where he, in view of sec 29 of the Magna Charta, refers to "the reign of law as opposed to arbitrary royal arrest."

25. That section, which has often been described as the bulwark of modern liberties, reads as follows: "No Freeman shall be taken, or imprisoned, or be disseised of his Freehold, or Liberties, or free Customs, or be outlawed, or exiled, or any otherwise destroyed; nor we will not pass upon him nor condemn him, but by lawful Judgment of his Peers, or by the Law of the Land. We will sell to no man, we will not deny or defer to any man either Justice or Right."

26. Op cit, 17

27. The rule of law and absolute sovereignty, in 106 "University of Pennsylvania Law Roview" 1958, 943. 


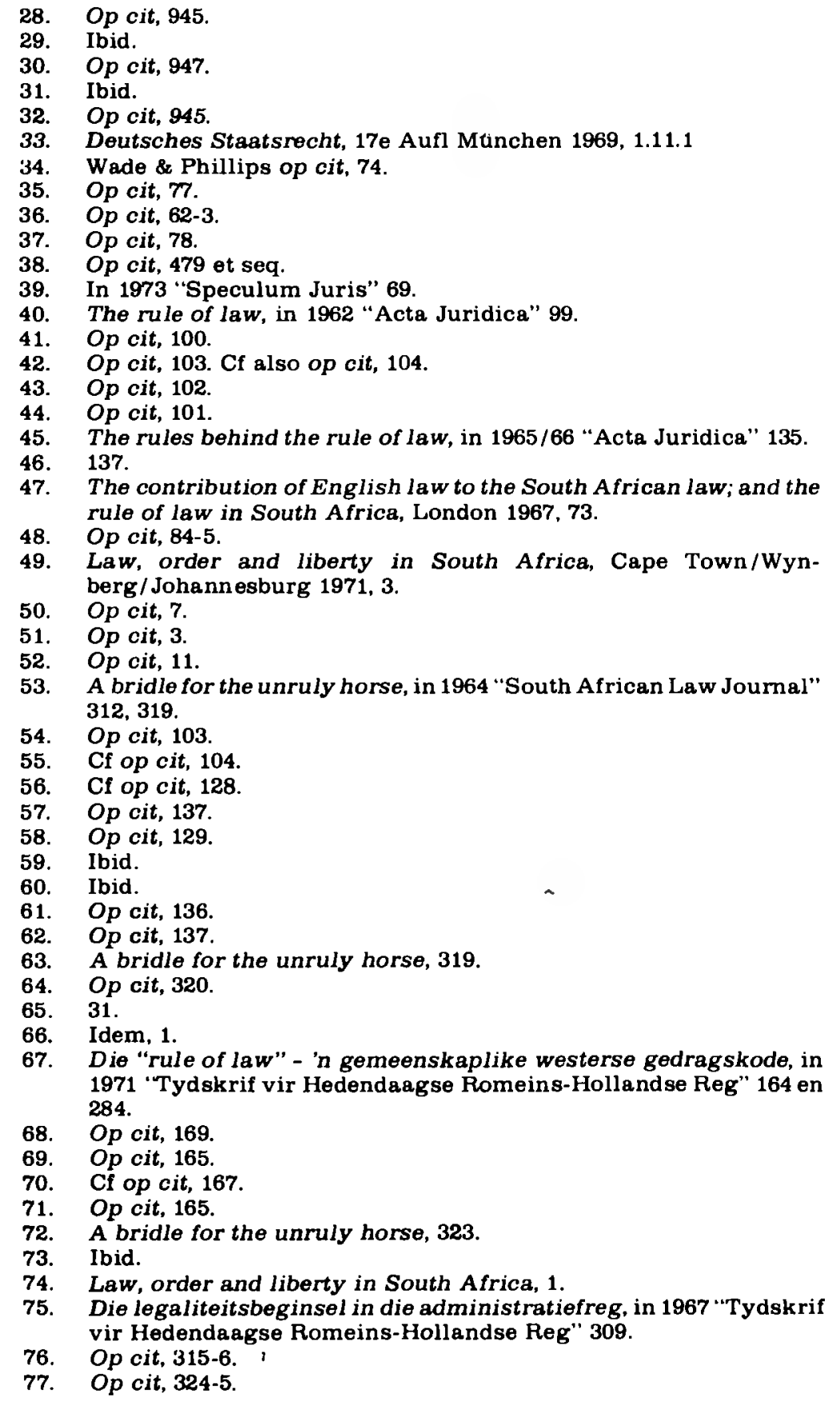


78. Op cit, 84

79. Act 32 of 1962.

80. $86-7$.

81. A bridle for the unruly horse, 321 . 